RESEARCH PAPERS

\title{
SUSTAINABLE CORPORATE RESPONSIBILITY - THE FOUNDATION OF SUCCESSFUL BUSINESS IN THE NEW MILLENNIUM
}

\author{
Schüz, M.
}

There are many reasons to reconsider the terms "corporate responsibility" and "sustainability". Despite their inflationary use, there is still no convincing concept, which combines these terms. This paper, for the first time, presents a holistic model of "Sustainable Corporate Responsibility" (SCR) mirroring all its different scopes in space and time. It outlines a philosophically founded introduction into the terms of "corporate responsibility" and "sustainability" and how they are interlinked. It, furthermore, emphasises a holistic understanding for what and to whom one should take on responsibility: In order to realise sustainable success in business economic, social and ecologic responsibility has to be taken equally into consideration. The model describes the possible ramifications of SCR constructions, highlighting typical company-profiles and, eventually, allowing better comparability. This way, best practice can be determined and highlighted more comprehensively.

JEL Classification: M14

\section{Introduction}

Both the global financial crisis and the nuclear catastrophe of Fukushima have awakened many companies to reconsider their business concept. These crises have forced them to rethink their responses to a wide range of stakeholderdemands. Although they are willing to take on "more" Corporate Responsibility and commit to sustainability, they have difficulties to understand these terms and how to apply them in daily work. Much like in the Babylonian Confusion, there are too many conflicting definitions of these terms.

Therefore, this paper provides a philosophically based introduction into the concepts of "corporate responsibility" and "sustainability" as well as their application to daily business. It broadens readers' minds towards a holistic understanding of which kind of responsibility they should be taking on and to whom.

For the first time, a model of Sustainable Corporate Responsibility (SCR) is presented in this paper mirroring all its different scopes. It also discloses the gaps between desired and actual responsibilities and therefore serves as tool for implementation. The model is useful firstly to plan for the future, secondly to evaluate the present, and thirdly to assess past activities of a company regarding their economic, social and ecologic impacts: Thus, the application of the model supports companies in all these three fields enabling them to realise sustainable success.

The model presented outlines all different approaches regarding sustainable corporate responsibility - be it fully economic and short-term oriented, or be it fully ethically ecologically and long-term oriented. Typical variations of company-profiles can be derived from the model. Comparisons between the states of corporate responsibility, companies have achieved, can be easily drawn and communicated. Moreover, gaps between delusion and reality can be illustrated.

In its first part, the paper sets out some reasons why Sustainable Corporate Responsibility (SCR) is an important driver for companies to be integrated into their business activities. Secondly, it clarifies the term responsibility, and discloses its deeper structure. Thirdly, the model of 
Triple Corporate Responsibility is outlined consisting of three main dimensions: the economic, the social and the ecologic. Fourthly, the concept of sustainability is integrated into the model of Sustainable Corporate Responsibility (SCR). The concluding part illustrates some possible applications of SCR.

\section{Drivers for Sustainable Corporate Responsibility}

The globalization of our economic world has mainly increased the productivity of enterprises. Low-cost productions allowed multinationals to augment their profitability tremendously. Simultaneously, they have been more and more scrutinized regarding negative externalities, such as social and ecologic damages caused by outsourcing productions.

Foxconn, main supplier for Apple's iPhone, is an example of this. Responsible for more than one million employees, it is still blamed for poor and dangerous working conditions, such as excessive and unpaid overtime, denial of ergonomic breaks, meagre wages, unfair treatment, inhumane management practises, as SACOM, the Hongkong based NGO "Students \& Scholars Against Corporate Misbehaviour", disclosed September 2012, based on 60 off-site interviews at Foxconn in Zhengzhou (SACOM, 2012). The company has even been blamed for using child-labour, recently (Hick, 2012). Protests, riots, suicides (NN, 2012) are the current effects of this corporate behaviour. Obviously, improvements promised by Apple's CEO Tim Cook in March 2012 (ts/dpa, 2012), have not yet been achieved.

Public pressure on companies to reduce negative social and ecologic impacts is immense. Petrobras' Chief Communication Officer, Izeusse Dias Braga, declared in a presentation to students during their study-trip through Brazil (Braga 2012), why they cannot neglect negative social and ecologic impacts of their businesses anymore: Three main issues drive them to integrate sustainability and corporate responsibility into their value creation chain: (a) “increasing expectations” by stakeholders, (b) “declining resources”, and (c) "radical transparency” through media, activists, NGOs, and new technologies such as Twitter, Facebook and Youtube.

Worldwide surveys confirm this statement. In 2010, Accenture interviewed 766 CEOs in 100 Countries and 25 Industries. $93 \%$ of them believed that sustainability issues will be critical to the future success of their business, and $72 \%$ cited "brand, trust and reputation" as one of the top three factors driving them to take action on sustainability issues (Accenture, 2010, p. 13). The largest report on corporate responsibility trends might be KPMG's “International Survey of Corporate Responsibility Reporting”, issued every three years and surveying thirty-four hundred companies worldwide. According to its 2011 report, 67\% (55\% in 2008) of the respondents saw "reputation and brand" as the most important driver for corporate responsibility activities, 58\% (69\% in 2008) stated "ethical considerations". Interestingly, "Economic considerations" declined from 68\% in 2008 to 32\% in 2011. (KPMG, 2011, p. 19) 2010, in its fourth "CSR Trends" survey of 602 companies in "dozens of countries" PWC confirms that besides economic issues, 81\% reported social and ecologic impacts of their businesses. (PWC 2010) Yet those studies do not disclose the gap between declared and lived, described and actual corporate responsibility activities. They illustrate "that business should generate high returns to investors but balance it with contributions to the broader public good”, as $84 \%$ of interviewed executives stated in a McKinsey Survey (cited by Wheelen, Hunger 2010, p. 122). Obviously the trend to integrate corporate sustainability and responsibility into businesses seems to be irreversible.

The sociologic tendency and the economic power of the LOHAS (= Lifestyle of Health and Sustainability) movement reinforce the pressure on enterprises. (Greenbiz Staff, 2007). Those companies meeting a certain standard of sustainability, such as healthy products, environmentally friendly productions etc. are rewarded by customer loyalty. Those who do not, are punished by consumer boycott. In short, the former gain competitive advantage, while the latter loose out (cf. Crawford, 2005).

Although the majority of executives agree upon the necessity of corporate sustainability and responsibility within all of their business activities, they do not agree on an understanding of the terms encompassed by the subject (cf. Blackmore, Chapman, Ison, 2012). Furthermore, the link between sustainability and responsibility has not yet been depicted. The following concept intends to fill this gap.

\section{The Structure of Responsibility}

First of all, we will define the term "responsibility". Stemming from the Latin term "respondere", it means someone has to answer the question: What have you done? Therefore, "responsibility" in philosophic reflection describes the relation between an acting subject causing effects, responding to and judged by an authority asking about their positive and negative impacts. (cf. Picht, 1969, p. 319). The structure of any responsibility is graphically illustrated in figure 1 .

Authorities evaluate the activity as responsible or irresponsible, condemning or praising it. Their verdict can diverge, because of their different value systems and their view of the effects. A Magistrate at court might absolve someone from his deed, while activists or his own conscience assess him as irresponsible. Usually, shareholders evaluate disasters differently than other stakeholders. Therefore, one can consider responsibility as a construction with different solutions (Bayertz 1995, p. 4). 
Figure 1: The structure of responsibility

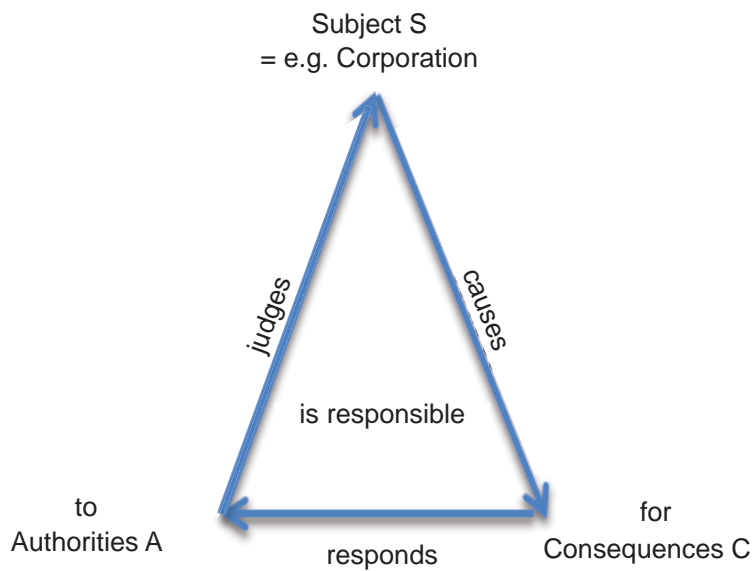

Source: author

For instance, the explosion of Tepco's nuclear power plant in Fukushima can be seen as an act of nature beyond control, caused by a tsunami. Consequently, the operating company can be absolved from blame. But, further investigations showed that Tepco had neglected many safety standards for economic reasons. With the construction of the plant, a protection barrier against tsunamis, 30 meters of height along the shore was proposed. However, the barrier subsequently built, only reached a height of 6 meters (Redaktion, 2012). Additionally, corrupt safety authorities were bribed by Tepco for accepting low safety standards. Neglected duties of care, mismanagement, corruptive practices for the sake of profit-maximization were jointly responsible for the catastrophe with tremendous social and ecologic impacts. Thus, "the public has targeted Tepco, Japanese politicians, nuclear experts and the media, which has promoted the myth of safe nuclear plants for the past 50 years”, as Satoko Kogure, a freelance journalist based in Japan, stated (Kogure, 2012). From his point of view, Tepco and its executives should be held responsible for the disaster, while government still tries to exculpate them. However, the example shows that responsibility is a veriable term, depending on how one assesses consequences and which authority is accepted.

\section{The Triple Corporate Responsibility}

But what should corporate responsibility comprise? There are good reasons to firstly distinguish three dimensions, and secondly different scopes of it - from short to broad.

Philosophically, the three dimensions of responsibility mirror the three fundamental attributes of all being - not more and not less. As Aristotle already stated, all living beings consist of physical, social and mental dimensions, embedded within the whole cosmos. All other aspects can be reduced to these dimensions. In scientific language, biologic systems are openly embedded in their social and ecologic environment with which they exchange resources. They have to respond to them regarding negative undesired side-effects which they have caused. Otherwise, the environment will strike back - a high risk for their own survival (cf. Schüz, 1999, p. 38ff, 49 f).

Like biological systems, social systems such as companies can only survive in the long run, when they cooperate with other systems (e.g. represented by stakeholders) to fit in the greater whole in other words: when they find their ecological niche or meaning of life. Thus, corporate health can only be sustained when physical, social and mental resources are exchanged fairly. An industrial company needs physical resources such as financial capital, raw materials, buildings, it also needs social resources such as suppliers, employees, customers, and mental resources such as ideas, inventions and strategies, allowing them to provide meaningful products and services all of which represent their ecologic niche. When those resources are gathered at the expense of the environments, they might be withdrawn. Without the support of its environments the company will eventually dry out. (cf. Schüz 1999, p.116 ff) Thus, it should pursue "enlightened self-interest" (cf. Ikerd 1999) to take on responsibility that creates stakeholders' trust, assuring low transaction-costs, inducing willingness to cooperate longterm, and protects its own conditions for existence. Besides the economic responsibility, the dimensions of social and ecologic responsibilities are fundamental for sustaining long-term survival.

These dimensions have to be balanced, because they are often conflicting at first view. Social and ecologic engagements seem to harm economic results. But they are investments which yield returns through stakeholders' cooperation in general, and especially customer loyalty. If not taken, the neglected environments withdraw confidence in the company, causing high economic losses in the long run.

Consequently, one can define (fig. 2) corporate responsibility as the following: A manager/ company acts responsibly, when he/ it is responding for the consequences of his/ its actions, towards authorities - economically for being profitable to shareholders, socially for getting along well with all stakeholders, and ecologically for acting sensibly and respectfully towards nature or being. Through responding to shareholders, self-preservation is provided; through responding to ethical demands, co-preservation with stakeholders is enabled; through responding to „nature“ or „being“, preservation of the whole is contributed to. (Schüz 1999, p. 76 f) 
Figure 2: The Triple Corporate Responsibility

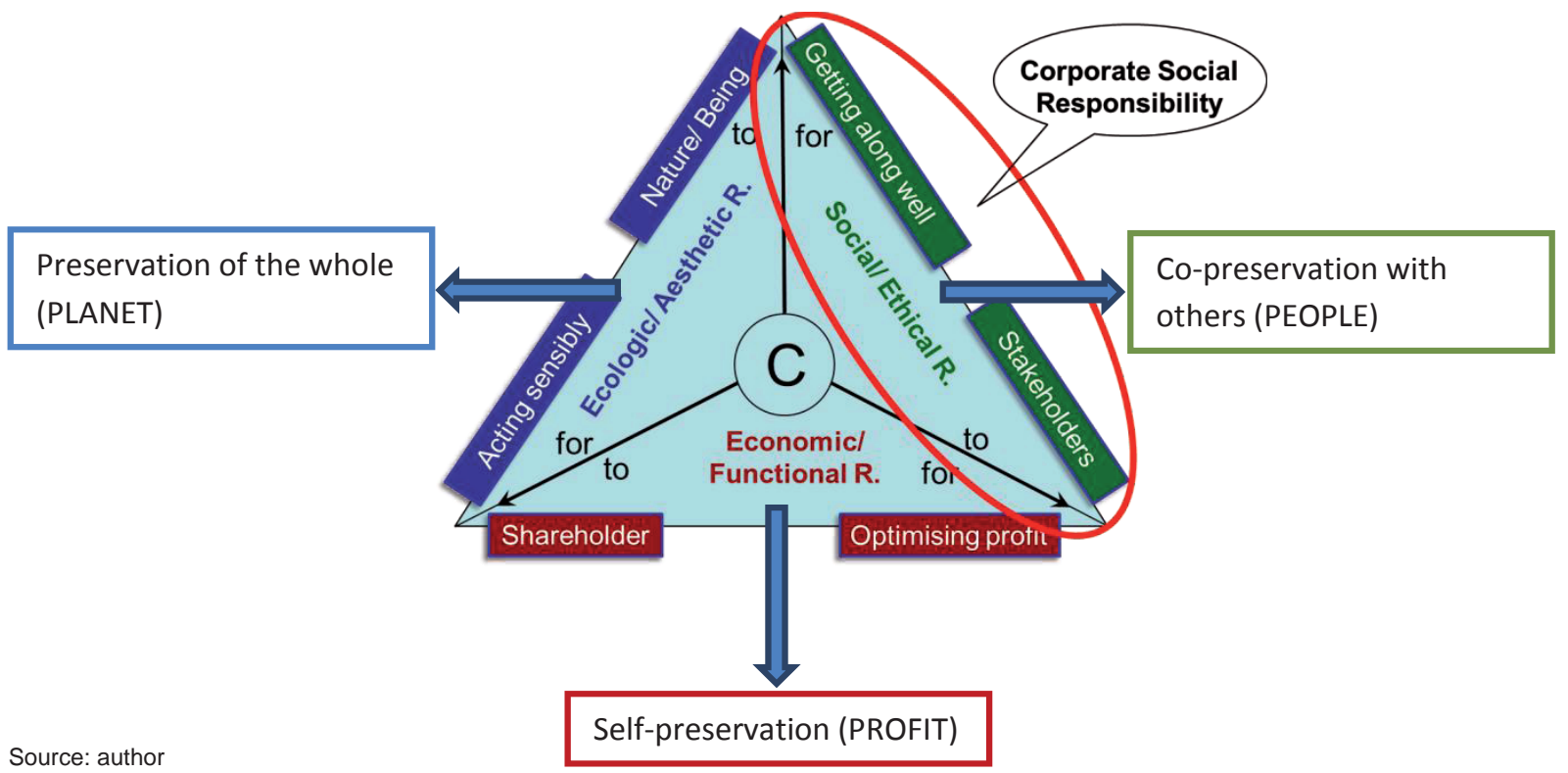

Figure 2 outlines the Triple Corporate Responsibility with its different consequences and authorities. As one can see, the commonly used term "Corporate Social Responsibility" represents only the social dimension of corporate responsibility. Interestingly, one can connect the main three traditional ethical concepts with this dimension: Virtue ethics strengthens the company's ability for taking responsibility, while the utilitarian ethics assesses the consequences as beneficial or damaging, and deontologic ethics defines the authority asking for the fulfilment of ethical duties. Those concepts are not fighting each other, but eventuelly complementing one another, when linked to the term of ethical responsibility. (Schüz, 1999, p. 174 ff.)

The majority of the actual debate is still focusing on social responsibility, because ecological issues can be reduced into it. (cf. Mey, Cheney, Roper, 2007) As suggested, there are e. g. NGOs such as Greenpeace defending the needs for natural environment. Thus, it would suffice to negotiate with them in order to meet nature's needs.

However, from the Triple Corporate Responsibility perspective, this approach is only one side of the coin. It neglects that nature cannot simply been represented by social interest groups. Nature, respectively all life, speaks for itself and everyone should directly respond to it, because the impact of their activities on it is too individual and too unique. It cannot be handled by other institutions or organizations. Responsibility cannot be delegated. Hence, the ecologic responsibility has to be directly taken by the initiators.

Furthermore, the ecologic dimension has to be treated differently from the social dimension, which asks for ethical reflection. Ecology has to be approached esthetically. Only our senses allow perceiving what is beneficial or harmful for survival. Most of the negative influence can be seen immediately or instinctively, smelled, touched, heard, and tasted. Normally, our senses determine what is meaningful and what not. But civilization, technology and sciences have alienated mankind from nature. Thus, man has lost his orientation for viability through his dulled senses, and neglected that his exploitation of nature has continuously deprived nature of its self-healing power.

Therefore, ecological responsibility re-sensitizes man about activities which are harming nature; ecological responsibility appeals to man to minimize harmful actions by acting sensibly, which means using all his senses and reason. Concretely, Braungarts' and McDonough's initiative of “cradle to cradle” leads to the right track (2002). It is a challenge for education to widen the senses for nature's demand of its careful use. More research has to be done, on how managers and entrepreneurs can develop their ethical awareness as well as their esthetic sensibility about what is conducive and meaningful for the whole planet.

The idea of the "Triple Bottom Line", introduced by John Elkington (1998) paved the way for the "Triple-CorporateResponsibility" model. The former assesses the results of business activities, regarding their economic, social, ecological impacts. Meanwhile, it is applied in different ways. For instance, the Global Reporting Initiative is structured after the Triple Bottom Line (GRI, 2012) as well as the Swiss rating agency SAM, which evaluates companies according to their economic, social and ecologic balance sheet. Within their industry, best practicing companies are listed in the Dow Jones Sustainability Index (DJSI) (SAM, 2012). 
Figure 3: Different Scopes of Responsibility

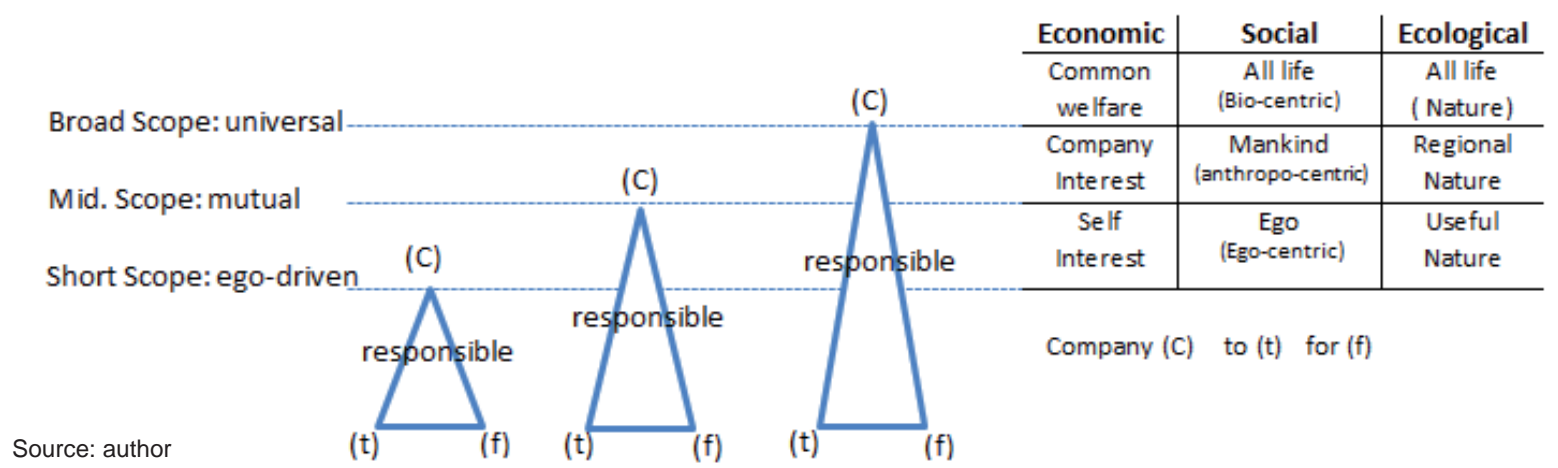

Moreover, the Triple Corporate Responsibility-model tackles the root causes in order to improve behavior. For example, Shell and other companies (e.g. Siemens) have defined their corporate responsibility according to the Triple-P: Planet, People, Profit. They emphasize that these three responsibilities have to be balanced to a large extent, in order to achieve sustainable development. (cf. Shell 2012) How far and how seriously the three responsibility dimensions are considered or rather: concretely implemented, is not proven just by proclaiming them. Only practice shows, whether the social and ecological dimensions serve as fig leaves or are truly respected in daily business.

Our Triple-Corporate Responsibility-model illustrates this. It indicates different scores, how far the respective dimensions of responsibility are concretely taken. Three main scopes of responsibility are proposed following Jean Piaget (1973) and Lawrence Kohlberg (1971)': (a) the short scope striving for egoistic benefit, (b) the medium or mid scope striving for mutual or reciprocal benefit, (c) the broad scope striving for universal benefit. For illustration, the different scopes are outlined as triangles with different heights in the model of Sustainable Corporate Responsibility developed in the next section. According to figure 3, the scopes of each dimension can be concretized differently: Economic responsibility can range from self-interest to company-interest up to common welfare; social responsibility can reach from ego-centric,

1 Jean Piaget discovered that as children grow they show different stages of moral development. (1974) Lawrence Kohlberg continued Piaget's research also for adults. Both defined three main stages of ethical behavior: the "preconvential”, "convential”, and "postconventional level” (Kohlberg, 1971 163ff). While preconventional moral behavior is more egoistically responsive to sanctions and gratifications, the conventional moral is based on conventions and reciprocity. Only at the postconventional level the actor is oriented to universal principles based on autonomy apart from law and order which might represent only particular interests. anthropo-centric, to bio-centric orientation; ecological responsibility can reach from the focus on useful, to regional up to global nature. Detailed explanations of these categories suggested in the tables below are beyond the scope of this paper (cf. Schüz 2012).

\section{The concept of Sustainable Corporate Responsibility}

The Triple-Corporate Responsibility model described so far, still misses the dimension of sustainability. While the different scopes of the former are more related to space (e.g.: How far does responsibility reach on this planet?), the latter introduces the dimension of time. Time comes in, when it is considered how long responsible actions should last or be sustained. We can refer to the term "sustainability" as it was defined 1987 by the Brundtland Commission: "Sustainable development is development that meets the needs of the present without compromising the ability of future generations to meet their own needs” (Brundtland, 1987). In short, it declares not to create a disadvantage for future generations without explaining, whether this includes non-human generations such as animals and plants (bio-centric approach) or not (anthropo-centric approach). Moreover, it does not define what disadvantage means. Securing their survival or - more strongly - the same life-chances as we have?

In combination with our responsibility-model all the different ranges and scopes can be illustrated now quite easily. The model of Sustainable Corporate Responsibility (fig. 4) is shown as a clock with three different clock-faces representing the Triple Corporate Responsibility. The three clock-hands are used, to indicate the time period as well as the scope of responsibility achieved: The longer they are, the larger scope they represent. The longer the clock-faces march on, the more sustainable the responsibility is, in other words: the more impacts on future generations are considered. Like the different scopes, the range resp. grade of sustainability is divided in three steps: Short-, mid-, and long-term. 
Figure 4: Model of Sustainable Corporate Responsibility

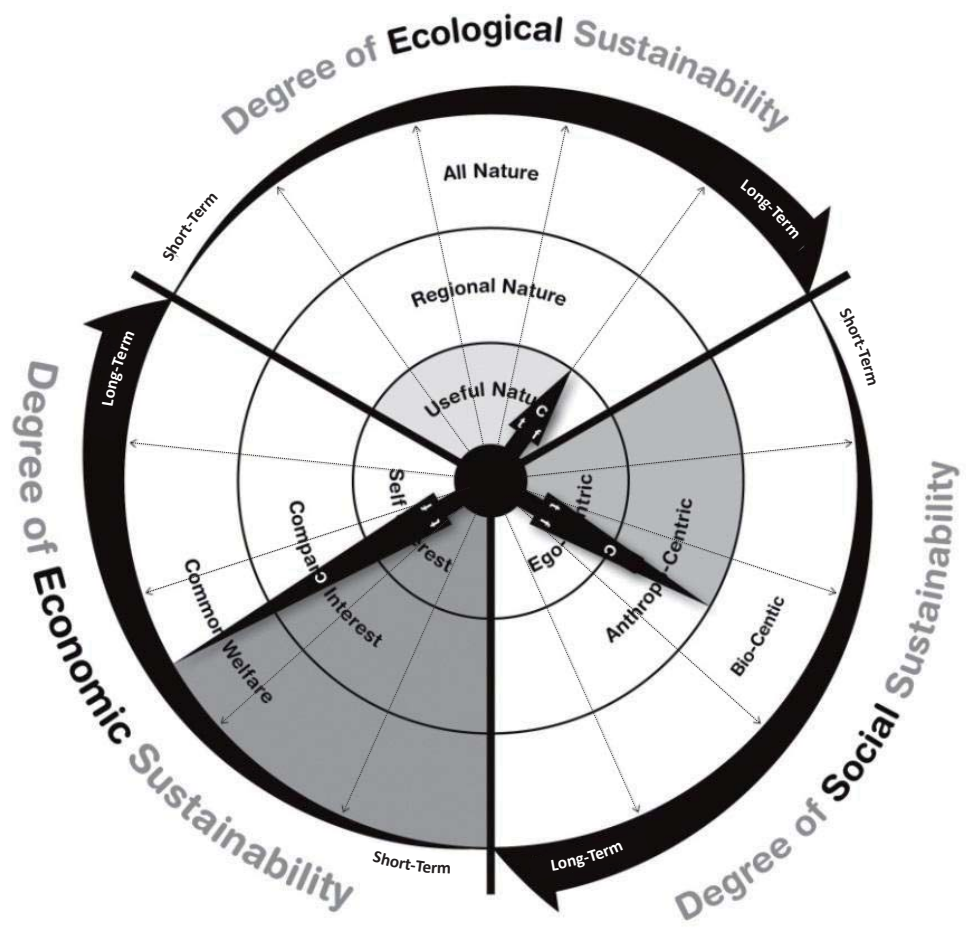

Source: author
Within the economic dimension, the shortterm oriented entrepreneur sees only the success of today without reflecting the consequences of tomorrow or in the later future. Being highly sustainable is not contradicting a short-scope in responsibility. The self-interested entrepreneur for instance, might think of his grand-grand children to inherit his company, without any respect for future generations of other human beings, not to mention other living beings. Also, investors can be very short-termoriented such as day-traders or hedgefund managers, while family enterprises or investment groups such as Berkshire Hathaway are really long-term oriented.

The following tables give an overview about scopes and grades of sustainability within the three dimensions of corporate responsibility with some examples. Especially the mentioned methods how to implement the respective responsibilities cannot be explained in the course of this paper in detail. All the items are suggestions and subject to further development. They shall inspire for how to implement SCR within all processes and supply chains of corporate activities.

Table 1: Scopes and Ranges of Economic Dimension of SCR

\begin{tabular}{|c|c|c|c|c|}
\hline \multicolumn{5}{|c|}{ Economic Dimension: Functional responsibility - What do we want? } \\
\hline \multirow{2}{*}{$\begin{array}{l}\text { Different Scopes: } \\
\text { a) short: self-interest } \\
\text { b) mid: company-interest } \\
\text { c) broad: common } \\
\text { welfare }\end{array}$} & \multirow[b]{2}{*}{$\begin{array}{l}\text { Methods/ } \\
\text { Concepts }\end{array}$} & \multicolumn{3}{|c|}{ Examples } \\
\hline & & Short-term & Mid-term & Log-term \\
\hline Company is responsible & $\begin{array}{l}\text { Value-Mana- } \\
\text { gement }\end{array}$ & $\begin{array}{l}\text { Success today } \\
\text { a) Shareholder Value } \\
\text { b) Customer Value } \\
\text { c) All stakeholder Values }\end{array}$ & $\begin{array}{l}\text { Success tomorrow } \\
\text { a) Shareholder Value } \\
\text { b) Customer Value } \\
\text { c) All stakeholder Values }\end{array}$ & $\begin{array}{l}\text { Success in future } \\
\text { a) Shareholder Value } \\
\text { b) Customer Value } \\
\text { c) All Stakeholder Value }\end{array}$ \\
\hline $\begin{array}{l}\text { for consequence of } \\
\text { Optimising Profit }\end{array}$ & $\begin{array}{l}\text { Risk-Mana- } \\
\text { gement }\end{array}$ & $\begin{array}{l}\text { Quarterly profit } \\
\text { a) Profit maximization } \\
\text { b) Win-win-orientation } \\
\text { c) Profit-for-all-orientation }\end{array}$ & $\begin{array}{l}\text { Annual profit } \\
\text { a) Profit maximization } \\
\text { b) Win-win-orientation } \\
\text { c) Profit-for-all-orientation }\end{array}$ & $\begin{array}{l}\text { Long-term profit } \\
\text { a) Profit maximaximization } \\
\text { b) Win-win-orientierung } \\
\text { c) Profit-for-all-orientation }\end{array}$ \\
\hline $\begin{array}{l}\text { to authority of } \\
\text { Shareholders }\end{array}$ & $\begin{array}{l}\text { Corporate } \\
\text { Governance }\end{array}$ & $\begin{array}{l}\text { Short-term investor } \\
\text { (e.g. daytrader, } \\
\text { hedge funds) } \\
\text { a) Black Knight } \\
\text { b) White Knight } \\
\text { c) Red Knight }{ }^{1}\end{array}$ & $\begin{array}{l}\text { Mid-term investor } \\
\text { (e.g. hedge funds, pension } \\
\text { funds) } \\
\text { a) Black Knight } \\
\text { b) White Knight } \\
\text { c) Red Knight }\end{array}$ & $\begin{array}{l}\text { Long-term investor } \\
\text { (e.g. family company, cf. } \\
\text { Berkshire Hathaway) } \\
\text { a) Black Knight } \\
\text { b) White Knight } \\
\text { c) Red Knight }\end{array}$ \\
\hline
\end{tabular}

Source: author

2 The black knight invests in companies for exploiting their assets short-term for his own sake, the white knight for mutual benefit. In contrast, the red knight, a new term personally proposed to author by the Viennese entrepreneur Christian Halper, puts his heart and soul into his investments in order to benefit all involved beings. 
Table 2: Scopes and Ranges of Social Dimension of SCR

\begin{tabular}{|c|c|c|c|c|}
\hline \multicolumn{5}{|c|}{ Social Dimension, Ethical Responsibility - What shall we do? } \\
\hline \multirow{2}{*}{$\begin{array}{l}\text { Different Scopes: } \\
\text { a) short: Ego-centric } \\
\text { b) mid: } \\
\text { Anthropo-centric } \\
\text { c) broad: Bio-centric }\end{array}$} & \multirow{2}{*}{$\begin{array}{l}\text { Methods/ } \\
\text { concepts }\end{array}$} & \multicolumn{3}{|c|}{ Examples } \\
\hline & & Short-term & Mid-term & Long-term \\
\hline $\begin{array}{l}\text { Company } \\
\text { is responsible }\end{array}$ & Virtue Ethics & $\begin{array}{l}\text { Best practice today } \\
\text { a) within own market } \\
\text { b) within industry } \\
\text { c) inside and outside } \\
\text { the organisation }\end{array}$ & $\begin{array}{l}\text { Best practice tomorrow } \\
\text { a) within own market } \\
\text { b) within industry } \\
\text { c) inside and outside } \\
\text { the organisation }\end{array}$ & $\begin{array}{l}\text { Best practice in future } \\
\text { a) within own market } \\
\text { b) within industry } \\
\text { c) inside and outside } \\
\text { the organisation }\end{array}$ \\
\hline $\begin{array}{l}\text { for consequence of } \\
\text { Getting Along Well }\end{array}$ & $\begin{array}{l}\text { Utilitarian } \\
\text { Ethics }\end{array}$ & $\begin{array}{l}\text { Present Generation } \\
\text { a) Benefit for Company } \\
\text { b) Benefit for mankind } \\
\text { c) Benefit for all living } \\
\text { beings }\end{array}$ & $\begin{array}{l}\text { Next Generation } \\
\text { a) Benefit for Company } \\
\text { b) Benefit for mankind } \\
\text { c) Benefit for all living } \\
\text { beings }\end{array}$ & $\begin{array}{l}\text { Future Generations } \\
\text { a) Benefit for Company } \\
\text { b) Benefit für mankind } \\
\text { c) Benefit for all living beings }\end{array}$ \\
\hline $\begin{array}{l}\text { to authority of } \\
\text { Stakeholders }\end{array}$ & $\begin{array}{l}\text { Deontological } \\
\text { Ethics }\end{array}$ & $\begin{array}{l}\text { Stakeholders today } \\
\text { a) internal (sharehol- } \\
\text { ders, managers, } \\
\text { employees) } \\
\text { b) external, direct (e.g. } \\
\text { customers, suppliers, } \\
\text { competitors, } \\
\text { residents, autorities) } \\
\text { c) external, indirect } \\
\text { (Environmentalists, } \\
\text { NGOs, UN Global } \\
\text { Compact etc.) }\end{array}$ & $\begin{array}{l}\text { Stakeholders tomorrow } \\
\text { a) internal (shareholders, } \\
\text { Managers, employees) } \\
\text { b) external, direct (e.g. } \\
\text { customers, suppliers, } \\
\text { competitors, residents, } \\
\text { autorities) } \\
\text { c) external, indirect } \\
\text { (Environmentalists, } \\
\text { NGOs, UN Global } \\
\text { Compact etc.) }\end{array}$ & $\begin{array}{l}\text { All future Stakeholders } \\
\text { a) internal (shareholders, } \\
\text { managers, employees) } \\
\text { b) external, direct (e.g. } \\
\text { customers, suppliers, } \\
\text { competitors, residents, } \\
\text { autorities) } \\
\text { c) external, indirect } \\
\text { (Environmentalists, NGOs, } \\
\text { UN Global Compact etc.) }\end{array}$ \\
\hline
\end{tabular}

Source: author

Table 3: Scopes and Ranges of Ecological Dimension of SCR

\begin{tabular}{|c|c|c|c|c|}
\hline \multicolumn{5}{|c|}{ Ecologic Dimension, Esthetical responsibility - What can we do? } \\
\hline \multirow{2}{*}{$\begin{array}{l}\text { Different Scopes: } \\
\text { a) short: Useful Nature } \\
\text { b) mid: Regional Nature } \\
\text { c) broad: All life/ Nature }\end{array}$} & \multirow{2}{*}{$\begin{array}{l}\text { Methodsl } \\
\text { Concepts }\end{array}$} & \multicolumn{3}{|c|}{ Examples } \\
\hline & & Short-term & Mid-term & Long-term \\
\hline $\begin{array}{l}\text { Company } \\
\text { is responsible }\end{array}$ & $\begin{array}{l}\text { Self-Ref- } \\
\text { lection }\end{array}$ & $\begin{array}{l}\text { Competence today } \\
\text { how to } \\
\text { a) use nature as resource } \\
\text { b) retain regional nature } \\
\text { c) tend all living beings }\end{array}$ & $\begin{array}{l}\text { Competence tomorrow } \\
\text { how to } \\
\text { a) use nature as resource } \\
\text { b) retain regional nature } \\
\text { c) tend all living beings }\end{array}$ & $\begin{array}{l}\text { Future Competence } \\
\text { how to } \\
\text { a) use nature as resource } \\
\text { b) Retaining regional nature } \\
\text { c) Retaining all living beings }\end{array}$ \\
\hline $\begin{array}{l}\text { for consequence of } \\
\text { Sensibly Acting }\end{array}$ & $\begin{array}{l}\text { Reflection } \\
\text { of Purpose }\end{array}$ & $\begin{array}{l}\text { Corporate Purpose } \\
\text { today } \\
\text { a) Damage-compensation } \\
\text { b) Nature-conservation } \\
\text { c) Full Integration into life } \\
\text { cycles ("cradle to cradle") }\end{array}$ & $\begin{array}{l}\text { Corporate Purpose } \\
\text { tomorrow } \\
\text { a) Ressource-conservation } \\
\text { b) Damage-compensation } \\
\text { c) Full Integration into life } \\
\text { cycles ("cradle to cradle") }\end{array}$ & $\begin{array}{l}\text { Corporate Purpose } \\
\text { in future } \\
\text { a) Ressource-conservation } \\
\text { b) Damage-compensation } \\
\text { c) Full Integration into life } \\
\text { cycles ("cradle to cradle") }\end{array}$ \\
\hline $\begin{array}{l}\text { to the authority of } \\
\text { Nature/ Being }\end{array}$ & $\begin{array}{l}\text { Holistic } \\
\text { Reflection }\end{array}$ & $\begin{array}{l}\text { Existential reason today } \\
\text { through } \\
\text { a) useful nature } \\
\text { b) regional nature } \\
\text { c) all life/ nature }\end{array}$ & $\begin{array}{l}\text { Existential reason today } \\
\text { through } \\
\text { a) useful nature } \\
\text { b) regional nature } \\
\text { c) all life/ nature }\end{array}$ & $\begin{array}{l}\text { Existential reason today } \\
\text { through } \\
\text { a) useful nature } \\
\text { b) regional nature } \\
\text { c) all life/ nature }\end{array}$ \\
\hline
\end{tabular}


Figure 5: Typical company profile regarding implemented SCR

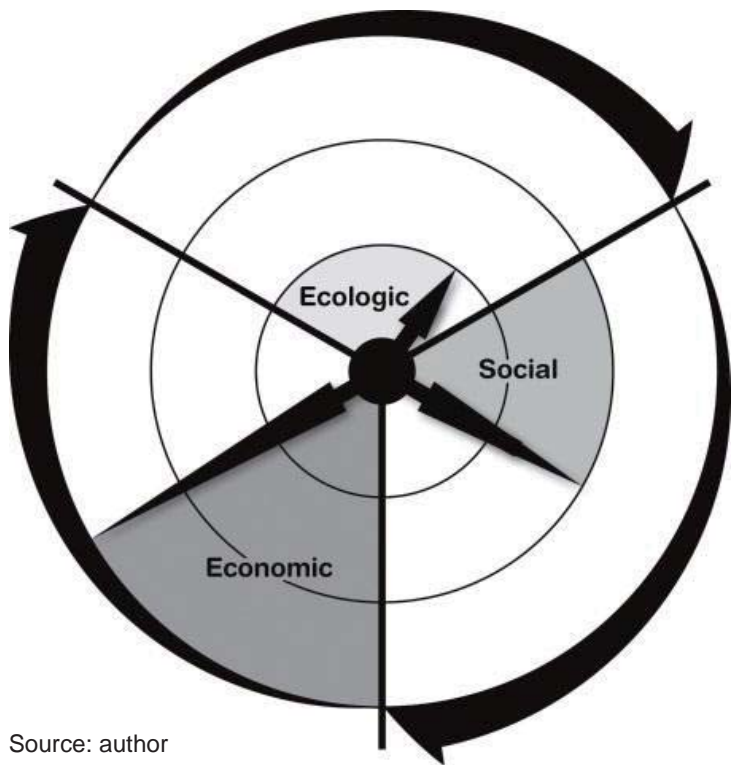

\section{Applications of the SCR-Model}

As mentioned at the beginning of this article, the model of SCR allows comparing different company profiles. At a glance, one can see the scope of responsibility and the grade of sustainability an enterprise has achieved resp. desired. Fig. 5 for example, describes a company focusing on economic responsibility in due consideration of common welfare, being ethically responsible for human beings, but only offering little respect for ecologic affairs.

Such profiles can also be extended by visualizing gaps between self-estimation regarding implementation of SCR and in the estimation of others, gained through detailed questionnaires and 360-degree surveys.

The next step should be to develop a typology of all combinations a company can strive for or realize, such as:

- Economistic enterprises primarily focusing on the economic dimension (EN) investing in the social dimension (SC) and the ecological dimension (EL) of SCR only when economic profit is higher than when neglecting them;

- Pragmatic enterprises balancing dimensions of SCR situationally EN = SC = EL;

- $\quad$ Real-idealistic enterprise $\mathrm{EN}<\mathrm{SC}=\mathrm{EL}$;

- Social enterprises primarily realizing the social dimension of SCR: EN $<$ SC $>$ EL dimension of SCR such as Caritas or the International Labor Organization (ILO);
- Ecologic enterprises primarily focusing to protect planet earth, such as Greenpeace or World Wide Fund with high scores of EL $>$ SC $>$ EN.

In all scenarios, the SCR-model is an important starting point for a new foundation of successful business in the new millennium. In the near future there will hardly be any enterprise and any business school that can totally neglect the social and ecologic dimensions when doing business respectively teaching it (cf. Prandini, Vervoort, 2012). Too many forces will drive the corporate world to consider its effects on the social and ecological environments. If not, they will be punished by the market - a risk only corporate blindness and ignorance might allow. The current riots at Foxconn in China already demonstrate this trend today. This might be just a faint suspicion (or gentle anticipation?) of what may await us in the near future of our globalized and well informed world, where suppression of stakeholder-interests and nature's integrity will no longer be accepted and lead to fatal counter-attacks.

\section{References}

Accenture (2010): UN Global Compact - Accenture CEO Survey, (accessed May 15, 2012), [available at http://www.unglobalcompact.org/docs/news_events/8.1/UNGC_Accenture_ CEO_Study_2010.pdf].

Ararat, M., Göcenoglu, C. (2006). Drivers for Sustainable Corporate Responsibility, Case of Turkey, (accessed October 10, 2012), [available at http://gocenoglu.net/CSRTurkeyMDF5.pdf]

Bayertz, K. (1995). Eine kurze Geschichte der Herkunft der Verant-wortung, in Verantwortung - Prinzip oder Problem, ed. Bayertz, K., Darmstadt: Wissenschaftliche Buchgesellschaft, 3-71.

Blackmore, C., Jake Chapman, J., Ison, R. (2012). Systems thinking: Understanding sustainability, The Open University, (accessed September 26, 2012), [available at http://openlearn. open.ac.uk/mod/oucontent/view.php?id=405678].

Braungart, M., McDonough, W. (2002). Cradle to Cradle - Remaking the Way We Make Things. New York: North Point Press.

Braga, Izeusse Dias (2012). Sustainable Business Activities at Petrobras, (presentation at Petrobras January 26, 2012), Rio de Janeiro.

Brundtland Commission (1987). Our Common Future - Towards Sustainable Development, chap. 2, World Commission on Economic Development (WCED), [accessed September 24, 2012), [available at http://www.un-documents.net/ ocf-02. htmI].

Ernst \& Young (2012). Six Growing Trends in Corporate Sustainability - An Ernst\&Young Survey in cooperation with GreenBiz Group, (accessed September 24, 2012), [available at http://www.greenbiz.com/sites/default/ files/1112-vey1315117_CCaSS_SixTrends_FQ0029_ lo\%20res\%20revised\%203.7.2012.pdf]. 
Crawford, D. (2005). The Balanced Scorecard and Corporate Social Responsibility: Aligning Values for Profit, (accessed September 25, 2012), [available at http://www.greenbiz.com/ news/2005/10/23/balanced-scorecard-and-corporate-socialresponsibility-aligning-values-profit].

Elkington, J. (1998). Cannibals with Forks: The Triple Bottom Line of the $21^{\text {st }}$ Century. Michigan: New Society Publishers.

Greenbiz Staff) (2007). LOHAS Forum Sees Big Growth in Green Marketplace, (accessed May 23, 2012), [available at http://www.greenbiz.com/news/2007/05/29/ lohas-forum-sees-big-growth-green-marketplace.

GRI (2012). Reporting-Guidelines, (accessed September 24, 2012), [available at https://www.globalreporting.org/resourcelibrary/ G3.1-Sustainability-Reporting-Guidelines.pdf].

Hick, M. (2012). Children Found Working In Foxconn iPhone Factory, (accessed September 25, 2012), [available at http:// www.huffingtonpost.co.uk/2012/01/17/children-found-working-in-iphone-foxconn-factory_n_1209953.html].

Ikerd, J. (1999). Rethinking the Economics of Self-Interests, (accessed September 27, 2012), [available at http://web. missouri.edu/ikerdj/papers/Rethinking.html].

Kogure, S. (2012). A lesson not yet learned, (accessed September 26, 2012), [available at http://www.ibanet.org/Article/Detail. aspx?ArticleUid=6c2935ff-c51d-4254-a334-4f5fbc5667d4].

Kohlberg, L. (1971). From Is to Ought, in Cognitive Development and Epistemology, ed. Mischel, T., New York: Academic Press, 151-235.

KPMG (2011). KPMG International Survey of Corporate Responsibility Reporting 2011, (accessed May 23, 2012), [available at http://www.kpmg.com/global/en/ issuesandinsights/ articlespublications/corporate-responsibility/pages/ 2011-survey.aspx].

Mey, S., Cheney, G., Roper, J. (Ed.) (2007). The Debate over Corporate Social Responsibility. Oxford: University Press.

NN (2012). Foxconn: Suizide bei Mitarbeitern, Die Welt kompakt, September 25, 2012, [available at http://www.welt.de/print/ welt_kompakt/print_wirtschaft/article109439140/ FoxconnSuizide-bei-Mitarbeitern.html].

Piaget, J. (1973). Das moralische Urteil beim Kinde. Frankfurt a. M.: Suhrkamp.

Picht, Georg (1969). Der Begriff der Verantwortung”, in Wahrheit - Vernunft - Verantwortung. Philosophische Studien, Stuttgart: Klett, 318-342.

Prandini, M., Vervoort Isler, P., Barthelmess, P., (2012). Responsible Management Education for 21st Century Leadership, Central European Business Review, 1 (2).
Radman Pesa, A., Belak, S., Belak, A. (2010). Sustainable Corporate Responsibility and Social Responsible Investment, (accessed October 10, 2012), [available at http://bib.irb.hr/ mzos/prikazi-rad?rad=497732].

Redaktion (2012). Wie oft muss Tepco in Fukushima die eigene Inkompetenz beweisen bevor eingeschritten wird?, (accessed October 2, 2012), [available at http://www.planetburgenland.at/2012/06/08].

PWC (2010). CSR Trends 2010, (accessed May 25, 2012), [available at http://www.pwc.com/ca/en/sustainability/ publications/csr-trends-2010-09.pdf].

SACOM (2012). New iPhone, Old Abuses: Have working conditions at Foxconn in China improved?, (accessed September 25, 2012), [available at www.sacom.com].

SAM (2012). Company Assessment, (accessed September 25, 2012), [available at http://www.sam-group.com/int/ sustainability-services/company-assessment.jsp].

Shell (2012). Sustainable Development, (accessed September 25, 2012), [available at http://www.shell-livewire.org/businesslibrary/employing-people/management/ sustainable-development].

Schüz, M. (1999). Werte - Risiko - Verantwortung. Dimensionen des Value Managements. München: Gerling Akademie Verlag.

Schüz, M. (2012). Grundlagen der ethischen Unternehmensverantwortung, SML Essentials No 1, Winterthur: School of Management and Law, in preparation.

ts/dpa (2012). Foxconn-Arbeiter sterben fürs iPad, (accessed September 25, 2012), [available at http://www.managermagazin.de/unternehmen/it/0,2828,druck824713,00.html].

Wheelen, T., Hunger, D. (2010). Strategic Management and Business Policy, New Jersey (12th ed.).

Author

Prof. Dr. phil. Mathias Schüz Deputy Head of Center for International Business School of Management and Law Zurich University of Applied Sciences (ZHAW) Stadthausstrasse 14 $\mathrm{CH}-8400$ Winterthur mathias.schuez@zhaw.ch 